\author{
EWA JOACHIMIAK \\ Pracownia Cytoszkieletu i Biologii Rzęsek \\ Zakład Biologii Komórki \\ Instytut Biologii Doświadczalnej im. M. Nenckiego PAN \\ Pasteura 3, 02-093 Warszawa \\ E-mail: e.joachimiak@nencki.gov.pl
}

\title{
BIOGENEZA CENTRIOLI
}

\section{WSTEP}

Centriole to występujace u zwierzat struktury mikrotubularne, które w toku ewolucji powstały $z$ przekształcenia ciałek podstawowych i, co ciekawe, w pewnych warunkach moga ponownie być przekształcone w te struktury. Zrab centrioli stanowi dziewięć tripletów mikrotubularnych rozmieszczonych regularnie na obwodzie okręgu (patrz JOACHIMIAK w tym zeszycie KOSMOSU). Komórki somatyczne $\mathrm{w}$ fazie G1 (komórki po zakończeniu podziału komórkowego) lub G0 (komórki zróżnicowane) zawieraja dwie centriole, tzw. centriolę matczyną i centriolę potomna, wchodzace $\mathrm{w}$ skład centrosomu (wyjątkiem są niektóre typy komórek, w których dochodzi do degradacji centrioli i centrosomu). Centrosom pełni niezwykle istotne funkcje zarówno w komórkach spoczynkowych (niedzielacych się), jak i w trakcie podziału komórkowego. W interfazie centrosom stanowi główne (lecz nie jedyne) centrum organizacji mikrotubul (ang. microtubule organizing center, MTOC), uczestnicząc w regulacji kształtu komórki, rozmieszczenia i integralności organelli, transportu wewnattrzcytoplazmatycznego czy odpowiedzi na sygnały zewnątrzkomórkowe. Natomiast podczas mitozy, dwa centrosomy (zawierajace po dwie centriole) staja się biegunami wrzeciona kariokinetycznego, umożliwiając równy rozdział chromosomów do komórek potomnych.

Centriole pełnia także istotna rolę niezależne od centrosomu. W interfazie centriola matczyna przekształcana jest $\mathrm{w}$ ciałko podstawowe, $z$ którego wyrasta tzw. rzęska pierwotna, będaca organellum sensorycznym w większości typów komórek zwierzęcych (patrz POPRZECZKO i współaut. w tym zeszycie KOSMOSU). Wyjątkiem sa komórki nabłonków orzęsionych i nabłonka węchowego, w których występuje do kilkuset centrioli przekształconych w ciałka podstawowe, dajacych początek rzęskom ruchomym/węchowym.

Liczba centrioli w komórce jest ściśle regulowana. Zbyt duża ich liczba w komórkach proliferujacych (obserwowana $\mathrm{np}$. w licznych typach nowotworów) prowadzi do powstania większej liczby centrosomów, co skutkuje powstaniem wielobiegunowego wrzeciona podziałowego, nierównocennym rozdziałem chromosomów do komórek potomnych i niestabilnością genetyczna komórki. Z kolei zbyt mała liczba centrioli w komórkach nabłonków orzęsionych uniemożliwia wytworzenie odpowiedniej liczby rzęsek ruchomych. Powoduje to zmniejszony przepływ płynu mózgowo-rdzeniowego, spowolniony transport komórki jajowej do macicy (grożący ciaża pozamaciczną), a także mało wydajne oczyszczanie śluzowo-rzęskowe (usuwanie śluzu wraz $z$ zanieczyszczeniami $z$ dróg oddechowych), prowadzace do chronicznych infekcji dróg oddechowych, a nawet słaby węch (receptory węchowe umieszczone sa na przekształconych rzęskach w komórkach nabłonka węchowego).

Zarówno podział komórki, jak i różnicowanie nabłonków orzęsionych wymaga zatem powielenia liczby centrioli. Proces ten nazywany jest biogeneza lub duplikacja.. Jednak w komórkach dzielacych się centriole musza zostać powielone tylko raz, aby przed podziałem komórka zawierała dokładnie 4 centriole (dwa centrosomy), podczas gdy w ko-

Słowa kluczowe: centriola, deuterosom, duplikacja, struktura koła u wozu 


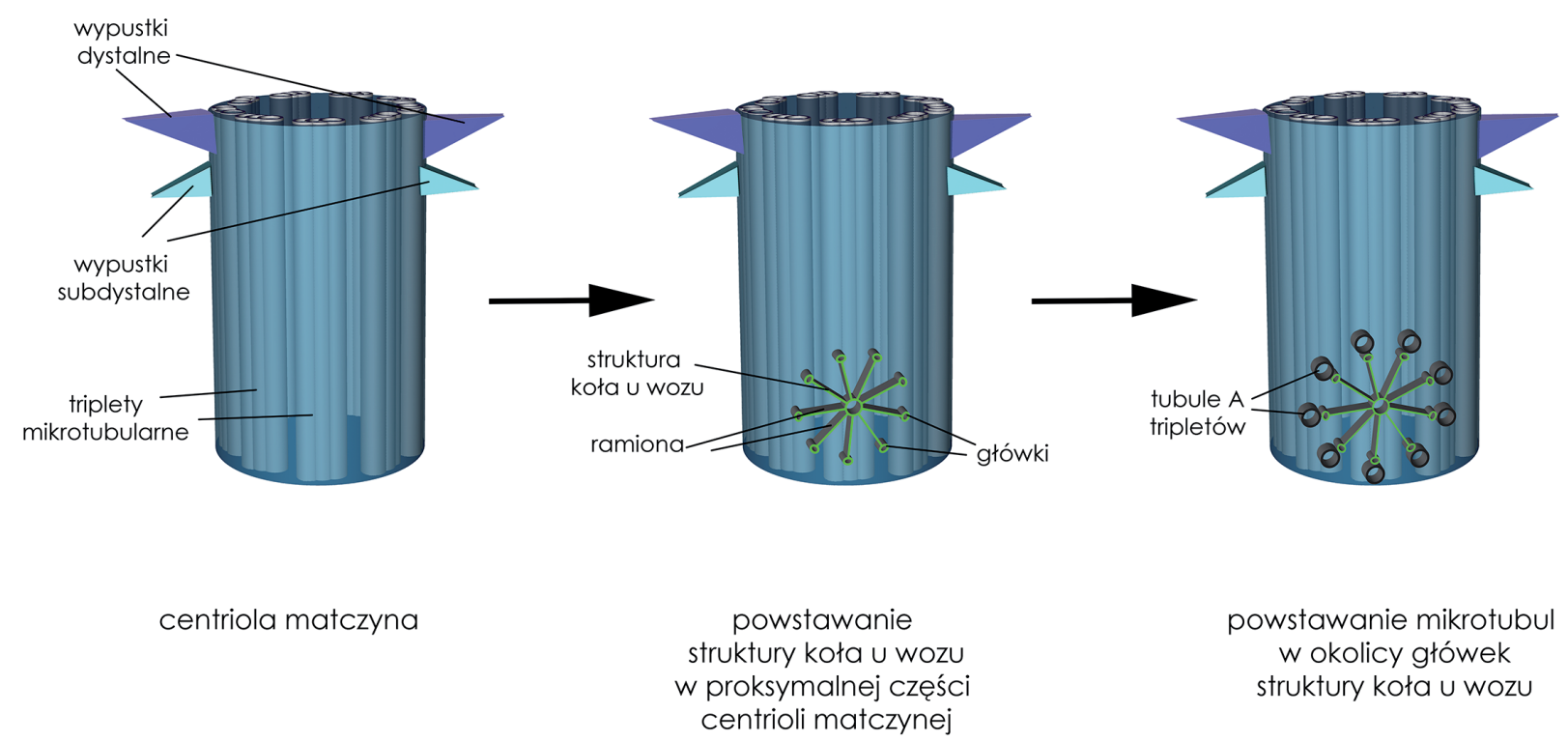

Ryc. 1. Etapy duplikacji centrioli na drodze „klasycznej”.

Szczegóły w tekście.

mórkach nabłonków orzęsionych musi dojść do ich wielokrotnego powielenia.

Tak duża różnica w liczbie tworzonych centrioli związana jest $z$ odmiennym mechanizmem biogenezy tych organelli. W komórkach proliferujących powielane sa one w procesie tzw. „klasycznej” duplikacji zwanej też „centriolarna”. Z kolei, w różnicujących komórkach nabłonków orzęsionych mamy do czynienia $z$ tzw. duplikacja „deuterosomalna".

Proces duplikacji centrioli badany był niezależnie przez wiele grup badawczych, $z$ wykorzystaniem kilku organizmów modelowych, w tym nicienia Caenorhabditis, muszki Drosophila i komórek ssaczych. Dlatego w większości przypadków białkom homologicznym nadano różne nazwy. $\mathrm{W}$ poniższym opisie użyte zostana nazwy białek/genów mysich.

\section{„KLASYCZNA” DUPLIKACJA CENTRIOLI}

Najlepiej poznana jest „klasyczna” ścieżka powielania centrioli w komórkach zwierzęcych (BANTERLE i GÖNCZY 2017).

Duplikacja centrioli centrosomu jest inicjowana wraz $\mathrm{z}$ wejściem komórki $\mathrm{w}$ fazę $\mathrm{S}$ cyklu komórkowego i przejawia się powstaniem $\mathrm{w}$ proksymalnej części każdej $z$ centrioli (zwanych odtad centriolami matczynymi) tzw. struktury koła u wozu (patrz JoACHIMIAK w tym zeszycie KOSMOSU). Następnie, w fazie S i G2, przy główkach struktury koła u wozu dochodzi do wytworzenia mikrotubul tripletów: najpierw powstaja pełne tubule A, a dopiero w późniejszych etapach dobudowywane sa bardziej zewnętrzne, niepełne tubule B i C (Ryc. 1).

Regulacja procesu powielania centrioli na drodze „klasycznej” jest wielopoziomowa, sprzężona $\mathrm{z}$ fazami cyklu komórkowego i bardzo ściśle kontrolowana. Jest to konieczne, ponieważ centriole, stanowiąc składnik centrosomu, buduja bieguny wrzeciona mitotycznego. Ich nadmiar mógłby spowodować powstawanie wielobiegunowego wrzeciona $\mathrm{i}$ nierównocenny rozdział chromosomów.

Jednym $\quad z$ kluczowych regulatorów w procesie duplikacji centrioli jest kinaza Plk4 (ang. Polo-like 4 kinase), która przyłączana jest do centrioli jeszcze $\mathrm{w}$ fazie G1 (czyli przez rozpoczęciem procesu powielania centrioli) za pośrednictwem białka Cep192 (Ryc. 2A). Jednak na tym etapie cyklu komórkowego kinaza jest nieaktywna.

Przejście punktu kontrolnego G1/S powoduje, że wokół istniejących (dwóch) centrioli zaczynaja być gromadzone w sposób hierarchiczny białka regulatorowe: CDK5RAP2, Cep152, Wdr62 i Cep63 (KoDANI i współaut. 2015). Białko Cep152 lokalizuje się w proksymalnej części centrioli i ma większe powinowactwo do kinazy Plk4 niż białko Cep192. Prawdopodobnie (choć nie do końca jest to jasne) to Cep152 powoduje, że kinaza Plk4, przemieszczana jest do strefy proksymalnej centrioli, gdzie nasteppnie dochodzi do interakcji pomiędzy Plk4 a jej głównym substratem, białkiem STIL (Ryc. 2B). Dotychczas nie ustalono, czy lokalizacja białka STIL przy centrioli zależy od 


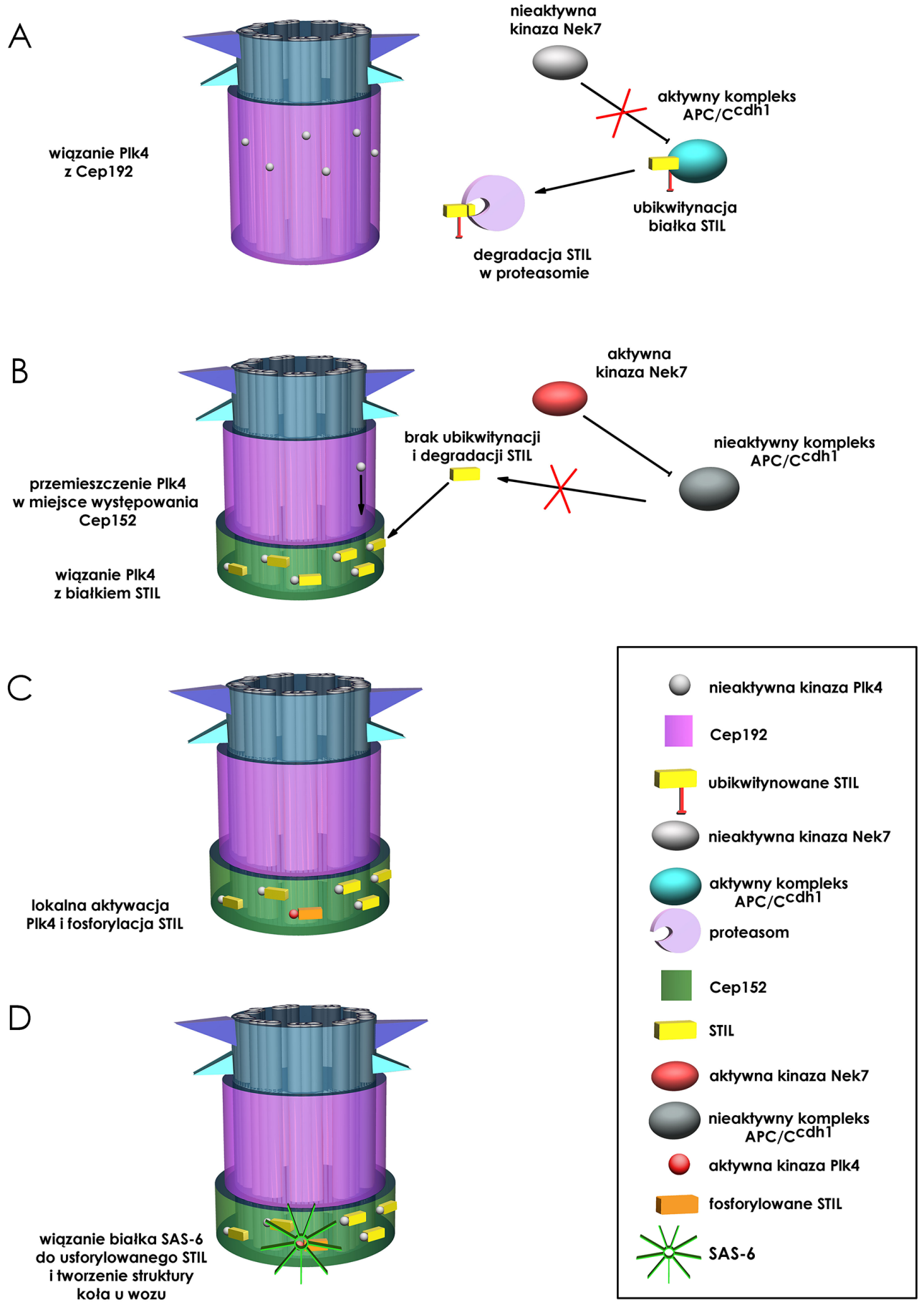

Ryc. 2. Regulacja inicjacji duplikacji centrioli na drodze „klasycznej”.

A. Nieaktywna kinaza Plk4 (szare kulki) wiąże się do centrosomu za pośrednictwem białka Cep192 (różowy cylinder). Jednocześnie białko STIL (żółty prostopadłościan) nie jest wiązane do centrosomu ponieważ ulega ubikwitynacji przez ligazę APC/C ${ }^{\text {Cdh1 }}$ (niebieska elipsoida) i degradacji w proteasomie (różowy kształt). B. Nieaktywna kinaza Plk4 przemieszczana jest do proksymalnego odcinka centrioli gdzie oddziałuje z białkiem Cep152 (zielony cylinder). Jednocześnie kinaza Nek7 (czerwona elipsoida) dezaktywuje ligazę APC/C ${ }^{\text {dh1 } 1}$ (szara elipsoida). Powoduje to brak ubikwitynacji białka STIL, które dołączane jest do centrioli, gdzie wiąże się z kinazą Plk4. C. Dochodzi do lokalnej aktywacji Plk4 (czerwona kulka) i fosforylacji białka STIL (pomarańczowy prostopadłościan). Miejsce to wyznacza pozycję powstawania centrioli potomnej. D. Ufosforylowane białko STIL wiąże białko SAS-6, co rozpoczyna powstawanie struktury koła u wozu (zielony kształt). 
kinazy Plk4, czy też zwiąana jest $z$ obecnościa innych czynników. Wiadomo jedynie, że poziom białka STIL jest regulowany poprzez jego degradacje, a zahamowanie tej degradacji jest zwiazane $z$ aktywnościa kinazy Nek7 $\quad z$ rodziny NIMA (ang. never in mitosis Aspergillus). Tak długo, jak kinaza ta pozostaje nieaktywna, białko STIL podlega degradacji zależnej od ligazy ubikwitynowej APC/ $\mathrm{C}^{\mathrm{Cdh} 1}$ (Ryc. 2A). Wydaje się, że aktywacja Nek7 dezaktywuje ligazę ubikwitynową APC/ $\mathrm{C}^{\mathrm{Cdh} 1}$, co umożliwia gromadzenie białka STIL w pobliżu centrioli (GUPTA i współaut. 2017) i kolejne etapy inicjacji duplikacji tej struktury (Ryc. 2B).

Plk4 lokalnie fosforyluje gromadzace się wokół centrioli białko STIL, co wyznacza miejsce powstania nowej centrioli (Ryc. 2C). Fosforylacja STIL ma kluczowe znaczenie, ponieważ $z$ jednej strony ufosforylowane białko STIL stabilizuje kinazę Plk4 (co wywołuje sprzężenie dodatnie aktywacji Plk4 i fosforylacji STIL), a $z$ drugiej, nabiera zdolności wiąania białka SAS-6. Gromadzace się białko SAS-6 organizuje się (przy udziale białka STIL) w dziewięcioramienna strukturę koła u wozu (Ryc. 2D) (patrz JOACHIMIAK w tym zeszycie KOSMOSU). W kolejnych etapach, do ramion SAS-6 dołaczane jest białko Cep135 (Bld10), które tworzy główki ramion, a także białko CPAP (BANTERLE i GÖNCZY 2017), które ma zdolność wiązania białek $Z$ rodziny tubulin, między innymi gamma-tubuliny. Dlatego w główkach ramion struktury koła u wozu gromadzona jest gamma-tubulina i dochodzi do nukleacji pojedynczych mikrotubul (tzw. tubul A). Aby możliwe było dobudowanie tubuli $\mathrm{B}$ i $\mathrm{C}$ i w rezultacie powstanie tripletów, niezbędna jest obecność dwóch niemikrotubularnych tubulin, delta- i epsilon-tubuliny. Wydłużanie mikrotubul tripletów, które zapoczątkowane jest w fazie $\mathrm{S}$ cyklu komórkowego, nie jest synchroniczne i trwa również w fazie G2. Najpierw wydłużaniu ulegaja tubule A i dopiero po osiagnięciu przez nie pełnej długości, dochodzi do wydłużania tubuli B i C (LI i współaut. 2012).

W powstawaniu centrioli bierze także udział ścieżka sygnałowa zwiazana $z$ cyklem komórkowym, $z$ udziałem kinaz Cdk2/cyklina A/E oraz Cdk1/cyklina B. Wykazano, że kinaza Cdk2 jest niezbędna w procesie proliferacji centrioli, jednak dotychczas nie wyjaśniono jaki jest jej udział w tym procesie. Udowodniono, że jednym $z$ substratów Cdk2, którego fosforylacja jest niezbędna dla inicjacji powstawania centrioli, jest białko Rb (Retinoblastoma), które w jądrze komórkowym oddziałuje $z$ czynnikiem transkrypcyjnym $z$ rodziny E2F (MERALDI i współaut. 1999). Po przemieszczeniu kompleksu Cdk2/cykli- na $\mathrm{A} / \mathrm{E}$ do jadra komórkowego dochodzi do fosforylacji białka $\mathrm{Rb}$, co skutkuje aktywacja czynnika transkrypcyjnego E2F (YAMASAKI 2003). Transkrypcja i synteza białek zależna od E2F wydaje się być niezbędna w procesie powstawania centrioli, choć nie zostało wykazane, które białka zwiazane $z$ proliferacja centrioli sa syntetyzowane pod wpływem aktywacji E2F.

Wydaje się, że substratami Cdk2 moga być również niektóre białka centrioli. W trakcie fazy $\mathrm{S}$ cyklu komórkowego, kinaza Cdk2 gromadzona jest w pobliżu centrioli w sposób zależny od białka Cep63, co sugeruje, że Cdk2 może fosforylować białka centrioli, niezależnie od swojej funkcji jądrowej (KODANI i współaut. 2015). Jak do tej pory nie ustalono jednak, czy i jakie białka centriolarne sa fosforylowane przez Cdk2 w fazie S i jaka mogłaby być rola tej fosforylacji.

$\mathrm{Z}$ kolei, w trakcie mitozy aktywna kinaza Cdk1/cyklina B, wiąże białko STIL. Powoduje to, że w trakcie podziału komórkowego białko STIL nie może oddziaływać $z$ kinaza Plk4, dlatego nie jest ona aktywowana. W rezultacie hamowana jest reduplikacja centrioli w fazie M, która mogłoby doprowadzić do destabilizacji genomu komórek potomnych (BANTERLE i GÖNCZY 2017).

$\mathrm{Na}$ duplikację centrioli wpływa również obecność łacznika pomiędzy centriola matczyna i potomną. W fazie G1 cyklu komórkowego centriole centrosomu połaczone sa ze sobą włóknista struktura, w skład której wchodzi białko C-Nap1 (zwane też Cep250). Przejście komórki do fazy $S$ wiąże się $z$ degradacja (lub depolimeryzacja) tego białka i fizycznym rozdzieleniem się centrioli. Tylko oddzielone centriole zdolne sa do rozpoczęcia procesu powielania (AGIRCAN i współaut. 2014).

Nie tylko inicjacja procesu powstawania centrioli, lecz także regulacja wydłużania tej struktury jest ściśle regulowana w cyklu komórkowym. Wykazano, że centriole potomne w trakcie fazy S osiagaja do $70 \%$ swej długości, a dokończenie wzrostu następuje dopiero w fazie G2. W komórkach sztucznie zatrzymanych w fazie S (np. poprzez podanie inhibitorów replikacji DNA) nie dochodzi do powstania centrioli pełnej długości i dopiero po wywołaniu fazy G2 (np. po usunięciu inhibitorów $z$ pożywki) komórki sa $w$ stanie wytworzyć prawidłowe centriole potomne (BANTERLE i GÖNCZY 2017).

Regulacja długości centrioli odbywa się głównie przy udziale kompleksu białek tzw. „czapeczki” (ang. cap), zlokalizowanej w dystalnej czéści centrioli. W skład tego kompleksu wchodzi m.in. wspomniane już białko CPAP. Ponadto, w kompleksie tym występuja ściśle ze soba oddziałujące białka CP110 
i Cep97 (patrz POPRZECZKO i współaut. w tym zeszycie KOSMOSU). Co ciekawe, CPAP i CP110/Cep97 wykazuja przeciwstawne działanie w procesie regulacji długości centrioli: CPAP promuje wydłużanie tej struktury, podczas gdy CP110/Cep97 hamuje jej wzrost. W skład kompleksu czapeczki wchodza także białka Cep120, SPICE1 oraz Cep295, które oddziałuja z CPAP, uczestnicząc w wydłużaniu centrioli, jednak mechanizm ich działania nie został wyjaśniony (COMARTIN i współaut. 2013). Z jednej strony dowiedziono, że tzw. domena LID białka CPAP, oddziałujac $z$ końcami plus mikrotubul centrioli, wpływa na tempo ich wzrostu (SHARMA i współaut. 2016), a nadprodukcja tego białka może doprowadzić do powstawania centrioli ze znacznie wydłużonymi mikrotubulami. Wskazywałoby to na kluczową rolę białka CPAP w procesie wydłużania centrioli. Z drugiej strony, ostatnio opublikowane badania (CHANG i współaut. 2016) wykazały, że brak białka Cep295 może zahamować proces wydłużania centrioli, nawet przy nadprodukcji białka CPAP wskazujac, że Cep295 ma większe znaczenie niż CPAP w aktywacji wzrostu mikrotubul centriolarnych. Ponadto, CPAP wraz z Cep135 sa niezbędne w kotwiczeniu Cep295 do centrio- li, co dodatkowo utrudnia zrozumienie mechanizmu wzajemnego działania tych białek, dlatego niezbędne sa dalsze badania w tym kierunku.

\section{„DEUTEROSOMALNA” DUPLIKACJA CENTRIOLI}

Znacznie mniej wiadomo o regulacji duplikacji ciałek podstawowych u organizmów jednokomórkowych. Morfologicznie proces ten przebiega podobnie jak „klasyczna” ścieżka powielania centrioli. Należy jednak pamiętać, że w przeciwieństwie do centrioli potomnej, nowopowstajace ciałka podstawowe, tuż po zakończeniu procesu duplikacji, sa podłaczane do błony komórkowej, gdzie pełnią swoją funkcję. Analiza genomów, a także liczne badania biochemiczne potwierdziły, że w procesie duplikacji ciałek podstawowych u jednokomórkowców biora udział homologi białek występujących u zwierząt: SAS-6, Cep135, gamma-, delta- i epsilontubulina. Wydaje się jednak, że procesy regulujace inicjację duplikacji ciałek podstawowych maja inny przebieg, przynajmniej u orzęsków, ponieważ w ich genomach nie występuja homologi białek takich jak Plk4 czy Cep192 (PEARSON i WINEY 2009).

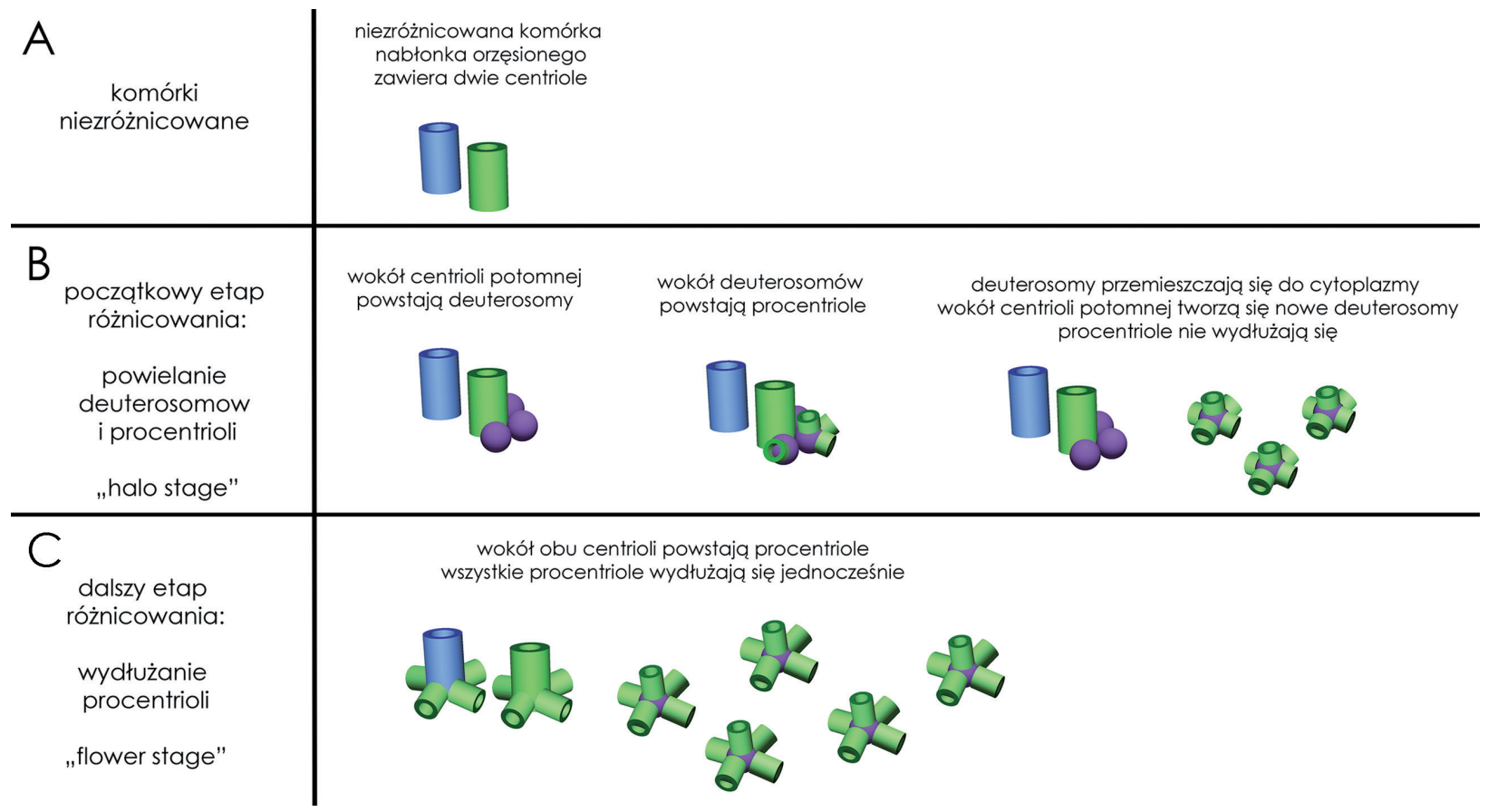

Ryc. 3. Powielanie centrioli na drodze „deuterosomalnej”.

A. Niezróżnicowane komórki nabłonka orzęsionego zawierają dwie centriole. B. Po rozpoczęciu różnicowania wokół centrioli potomnej dochodzi do niesynchronicznego powstawania licznych deuterosomów, przy których formowane sa procentriole. Na tym etapie mikrotubule procentrioli nie wydłużaja się. W literaturze anglojęzycznej ten etap nazywany jest „halo stage”. C. Po utworzeniu odpowiedniej liczby deuterosomów dochodzi do synchronicznej aktywacji wzrostu mikrotubul procentrioli. W tym samym czasie wokół centrioli również powstają procentriole. W literaturze anglojęzycznej ten etap nazywany jest „flower stage”. 
Jak już wspomniano, podczas różnicowania, komórki nabłonka orzęsionego wytwarzaja od kilkudziesięciu do nawet około 300 ciałek podstawowych (MEUNIER i AzIMZADEH 2016). Powstanie tak licznych ciałek, z poczatkowo dwóch centrioli obecnych w komórce, wymaga modyfikacji procesu duplikacji centrioli. I rzeczywiście, w różnicujących komórkach nabłonków orzęsionych przebieg biogenezy centrioli ma inny charakter niż w komórkach proliferujacych.

Jak każda komórka somatyczna, również komórki nabłonka orzęsionego przed różnicowaniem zawieraja jeden centrosom $z$ dwiema centriolami (Ryc. 3A). W trakcie różnicowania w komórkach nabłonka orzęsionego gromadzony jest fibrylogranularny materiał, tworzacy specyficzne struktury zwane deuterosomami. Wokół każdego deuterosomu powstaje kilka do kilkunastu zawiązków centrioli, tzw. procentrioli (Ryc. 3B). Co ciekawe, w różnych komórkach deuterosomy moga mieć odmienne rozmiary i dzięki temu tworzyć różna liczbę procentrioli. Przykładowo, w komórkach nabłonka dróg oddechowych powstaje około 50-100 deuterosomów o wielkości 100-200 nm, tworzących po kilka procentrioli, natomiast komórki ependymy (nabłonka wyściełającego komory mózgu) wytwarzaja mniej liczne, ale większe dueterosomy (do $500 \mathrm{~nm}$ ), tworzace nawet po kilkanaście procentrioli (YAN i współaut. 2016). Deuterosomy tworzone sa niesynchronicznie, a w okresie ich powstawania (ang. halo stage) procentriole nie ulegaja wydłużeniu (Ryc. 3B). Dopiero po zakończeniu powstawania deuterosomów, kiedy liczba procentrioli jest właściwa, wszystkie procentriole jednocześnie ulegaja wydłużeniu (ang. flower stage) (Ryc. 3C), a następnie podłączeniu do błony komórkowej, przekształceniu w ciałka podstawowe (ang. basal body stage) i orzęsieniu (AL JORD i współaut. 2014) (Ryc. 3).

Mechanizm molekularny procesu powielania centrioli na drodze "deuterosomalnej" jest bardzo słabo poznany. Nieliczne badania wskazuja, że deuterosomy powstaja w okolicach części proksymalnej centrioli potomnej, natomiast centriola matczyna nie bierze udziału w wytwarzaniu tych struktur. Na początkowym etapie różnicowania komórki nabłonków orzęsionych znacznie zwiększają poziom transkrypcji genów (tym samym podnoszac poziom białek) zwiazanych $z$ „klasyczna” droga duplikacji centrioli: CEP63, CEP152 i PLK4. Dodatkowo, syntezie ulega białko specyficzne wyłącznie dla tego typu komórek DEUP1 (zwane również CCDC67), które jest paralogiem (białkiem $z$ tej samej rodziny, o podobnej budowie pierwszo- $i$ drugorzędowej) białka Cep63, występujacym wyłącznie u kręgowców, $z$ wyjątkiem ryb promieniopłetwych (MEUNIER i AzIMZADEH 2016). DEUP1 prawdopodobnie oligomeryzuje w struktury sferyczne i wydaje się stanowić zrąb strukturalny i funkcjonalny deuterosomów (MEUNIER i AZIMZADEH 2016). Co ciekawe, „zmuszenie” komórek somatycznych mysich linii komórkowych NIH3T3 (fibroblasty) lub mIMCD3 (nabłonek kanalików nerkowych) do syntezy DEUP1 spowodowało powstanie struktur przypominajacych deuterosomy, zdolnych do tworzenia procentrioli (MEUnier i AZIMZADEH 2016). DEUP1, podobnie jak Cep63, ma zdolność wiązania Cep152 (MEUnier i AzIMZADEH 2016).

Jednak DEUP1 nie jest jedynym składnikiem deuterosomów, odpowiedzialnym za wiazanie Cep152. W deuterosomach występuje także białko CCDC78 o podobnej funkcji. Obniżenie ekspresji genu CCDC78 u Xenopus prowadzi do zmniejszenia puli białka Cep152 zwiazanej $z$ deuterosomami i w rezultacie obniżenia liczby centrioli w nabłonku orzęsionym (KLOS DEHRING i współaut. 2013).

W deuterosomalnej ścieżce duplikacji centrioli białko Cep152 pełni podobna rolę jak w ścieżce „klasycznej”, tzn. uczestniczy w podłączeniu kinazy Plk4 do deuterosomu. Nie wiadomo jednak, czy aktywacja Plk4 zwiazanej $z$ deuterosomem odbywa się $z$ udziałem tego samego mechanizmu, co w przypadku drogi „centriolarnej”. Być może nie, skoro deuterosom jest miejscem powstania wielu centrioli. Wiadomo jednak, że aktywacja Plk4 w deuterosomie (podobnie jak w ścieżce „klasycznej”) prowadzi do gromadzenia wokół tej struktury białek uczestniczacych w powstawaniu struktury koła u wozu i tripletów mikrotubul. Jednak, w przeciwieństwie do drogi klasycznej, na tym etapie nie dochodzi do wydłużenia mikrotubul tripletów (jak wspomniano, mikrotubule centrioli ulegaja wydłużeniu dopiero po powstaniu w komórce odpowiedniej liczby procentrioli). Mechanizm zapobiegajacy wydłużaniu tripletów i następnie wywołujacy ich synchroniczne wydłużanie jest nieznany.

Większość procentrioli w różnicujacych komórkach nabłonka orzęsionego powstaje na drodze „deuterosomalnej". Jednak jak się okazuje, deuterosomy nie sa jedynym miejscem tworzenia procentioli w tych komórkach. Badania ostatnich lat pokazały, że, dodatkowo, zarówno centriola matczyna, jak potomna sa miejscem powstawania procentrioli na drodze zbliżonej do „klasycznej”, $z$ tą różnicą, że powstaje wokół nich kilka procentrioli jednocześnie (Ryc. 3). Powstałe w ten sposób centriole stanowia nikły odsetek wszystkich ciałek podstawowych w komórkach nabłonka orzęsionego (AL JORD i współaut. 2014). 
Prawdopodobnie te dwie główne drogi powielania centrioli, „klasyczna” i „deuterosomalna”, nie sa jedynymi, które występuja w przyrodzie.

Przykładowo, w trakcie rozwoju embrionalnego zarodka myszy, ale nie szczura czy człowieka, komórki aż do stadium wczesnej blastocysty (stadium 64-komórkowe) dziela się $z$ udziałem centrów organizacji mikrotubul, w których występuje gamma-tubulina, ale brak jest centrioli (GUETH-HALLONET i współaut. 1993). Następnie, z udziałem nieznanego mechanizmu dochodzi do powstania centrioli „de novo", mimo braku wcześniej istniejacych struktur centriolarnych. Wydaje się też, że choć komórki ludzkie nie wykorzystuja w warunkach normalnych mechanizmu formowania centrioli „de novo", ewolucyjnie zachowały tę możliwość. Komórki siatkówki człowieka (linia komórkowa RPE-1) pozbawione delta-tubuliny charakteryzuja się niestabilnościa centrioli, które ulegaja rozpadowi tuż po zakończeniu podziału komórkowego. Następnie, w trakcie fazy S cyklu komórkowego odbudowuja centriole "de novo", przy czym często wykazuja one nieprawidłową budowę (WANG i współaut. 2017).

Choć obecny stan wiedzy pozwala na zrozumienie przebiegu duplikacji centrioli, szczególnie na drodze „klasycznej”, nadal do wyjaśnienia pozostaje wiele aspektów regulacji procesu powielania tych struktur. Znajomość tych mechanizmów może pomóc w zrozumieniu czynników wywołujacych niektóre patologie, tym samym przyczyniajac się do poszukiwania nowych terapii.

$$
\text { Streszczenie }
$$

Centriole sa mikrotubularnymi strukturami wchodzącymi w skład centrosomu, występującymi u zwierząt. Struktury te pełnia istotne funkcje zarówno podczas interfazy i mitozy komórek proliferujących, jak i w zróżnicowanych komórkach, włączając nabłonki orzęsione. Liczba centrioli w komórce jest ściśle kontrolowana, gdyż ich nadmiar lub niedobór prowadzi do zaburzeń podziału komórkowego lub funkcjonowania komórek. Centriole powstaja w procesie zwanym biogeneza lub duplikacją. W komórkach proliferujacych centriole sa powielane jeden raz, podczas gdy w komórkach nabłonków orzęsionych dochodzi do namnożenia większej ich liczby, co zwiazane jest $z$ odmiennym mechanizmem powielania tych organelli. W procesie tzw. „klasycznej” duplikacji, zwanej też "centriolarną", która ma miejsce w komórkach dzielących się, dochodzi do wytworzenia dwóch nowych centrioli. Z kolei podczas tzw. duplikacji „deuterosomalnej”, w różnicujących komórkach nabłonków orzęsionych wytwarzanych jest nawet kilkaset centrioli.

\section{LITERATURA}

AGircan F.G., Schiebel E., Mardin B. R., 2014. Separate to operate: control of centrosome
positioning and separation. Philos. Trans R Soc. Lond B Biol. Sci. 369, doi: 10.1098/ rstb.2013.0461.
Al JORD A., LEMAître A. I., DELGEHYR N., FAUCOURT M., SPASSKY N., MEUNIER A., 2014. Centriole amplification by mother and daughter centrioles differs in multiciliated cells. Nature 516,104-107.

BANTERLE N., GÖNCZY P., 2017. Centriole biogenesis: from identifying the characters to understanding the plot. Annu. Rev. Cell Dev. Biol. 33, 23-49.

Chang C. W., Hsu W. B., Tsai J. J., TANG C. J., TANG T. K., 2016. CEP295 interacts with microtubules and is required for centriole elongation. J. Cell Sci. 129, 2501-2513.

COMARTIN D., GuPTA G. D., Fussner E., COYAud É., HASEGAN M., ARCHINTI M., CHEUNG S. W., PincheV D., LaWo S., RAUGHT B., BAZETT-JONES D. P., LÜDERS J., PELleTIER L., 2013. CEP120 and SPICE1 cooperate with CPAP in centriole elongation. Curr. Biol. 23, 1360-1366.

Gueth-Hallonet C., Antony C., Aghion J., SanTA-MARIA A., LAJOIE-MAZENC I., WRIGHT M., MARO B., 1993. gamma-Tubulin is present in acentriolar MTOCs during early mouse development. J. Cell Sci. 105, 157-166.

GupTA A., TSUChIYA Y., OHTA M., SHIRATSUCHI G., KITAGAWA D., 2017. NEK7 is required for G1 progression and procentriole formation. Mol. Biol. Cell 28, 2123-2134.

Klos Dehring D. A., Vladar E. K., Werner M. E., Mitchell J. W., Hwang P., Mitchell B. J., 2013. Deuterosome-mediated centriole biogenesis. Dev. Cell 27, 103-112.

KODANI A., YU T. W., JOHNSON J. R., JAYARAMAN D., Johnson T. L., AL-Gazali L., SzTRIHA L., PARTLOW J. N., KIM H., KRUP A. L., DAMMERMANN A., KROGAN N. J., WALSh C. A., REITER J. F., 2015. Centriolar satellites assemble centrosomal microcephaly proteins to recruit CDK2 and promote centriole duplication. Elife 22, 4.

Li S., FERNANDEZ J. J., MARShall W. F., AGARD D. A., 2012. Three-dimensional structure of basal body triplet revealed by electron cryo-tomography. EMBO J. 31, 552-562.

MERAlDI P., LUKAS J., FRY A. M., BARTEK J., NIGG E. A., 1999. Centrosome duplication in mammalian somatic cells requires $E 2 F$ and Cdk2-cyclin A. Nat. Cell Biol. 1, 88-93.

MEUNIER A., AZIMZADEH J., 2016. Multiciliated cells in animals. Cold Spring Harb Perspect Biol. 8, doi: 10.1101/cshperspect.a028233.

PEARSON C. G., WineY M., 2009. Basal body assembly in ciliates: the power of numbers. Traffic 10, 461-471.

Sharma A., AHER A., Dynes N. J., Frey D., KATRUKHA E. A., JAUSSI R., GRIGORIEV I., CROISIER M., KAMMERER R. A., AKHMANOVA A., GÖNCZY P., STEINMETZ M. O., 2016. Centriolar CPAP/SAS-4 imparts slow processive microtubule growth. Dev. Cell 37, 362-376.

WANG J. T., KONG D., HOERNER C. R., LONCAREK J., STEARNS T., 2017. Centriole triplet microtubules are required for stable centriole formation and inheritance in human cells. Elife 6, doi: $10.7554 /$ eLife.29061.

YAMASAKI L., 2003. Role of the RB tumor suppressor in cancer. Cancer Treat. Res. 115, 209239.

YAN X., ZHAO H., ZHU X., 2016. Production of basal bodies in bulk for dense multicilia formation. F1000Res. 5, doi: 10.12688/f1000research.8469.1. 
KOSMOS Vol. 67, 1, 163-170, 2018

\section{EWA JOACHIMIAK}

Laboratory of Cytoskeleton and Cilia Biology, Department of Cell Biology, Nencki Institute of Experimental Biology PAS, 3 Pasteur Str.,02-093 Warsaw,E-mail: e.joachimiak@nencki.gov.pl

\section{BIOGENESIS OF CENTRIOLES}

\section{Summary}

Centrioles are microtubule-based organelles that in animal cells are a part of the centrosome. These structures play an important role during both interphase and mitosis in proliferating cells, as well as in differentiated cells, including ciliation of epithelial cells. The number of centrioles is strictly regulated as their excess or reduction leads to abnormalities in cell division or cell functions. Centrioles are formed in a process called biogenesis or duplication. In proliferating cells, centrioles are duplicated only once in each cell cycle, while in epithelial cells before ciliation, numerous centrioles are assembled, suggesting different mechanisms of duplication. During the so-called "classic" or "centriolar" duplication, in proliferating cells two new centrioles are formed before mitosis. By contrast, during differentiating into ciliated epithelial cells even few hundreds of new centrioles are assembled (so-called "deuterosomal" biogenesis).

Key words: cartwheel, centriole, deuterosome, duplication 